АНДРИЕЦ Галина Алексеевна,

канд. ист. наук, научный сотрудник Института истории, археологии и этнографии народов Дальнего Востока ДВО РАН (г. Владивосток).

Электронная почта: andriets2005@list.ru

\title{
Русские праздники Харбина начала XX века в системе духовных ценностей Дальнего Востока (на материале журнала «Железнодорожная жизнь на Дальнем Востоке»)
}

\author{
УДК 947.05(571.6)＜noBreak> DOI https://doi.org/10.24866/2542-1611/2021-3/27-35
}

В статье на материале журнала «Железнодорожная жизнь Харбин, на Дальнем Востоке» рассматриваются основные русские праздники г. Харбина дореволюционного периода как духовные ценности дальневосточного региона. Отмечено, что поселенцы из России в условиях иной культуры создали значительное культурное наследие, дошедшее до нас в виде печати. Определено, что большое внимание издание уделяло освещению массовых праздников и гуляний. Выявлены описания новогодних торжеств, общероссийских памятных дат, профессиональных юбилеев, детских праздников, народных гуляний. Автор приходит к выводу, что досуговая и просветительская деятельность журнала обеспечивала сохранение культурных традиций, норм, ценностей, что способствовало формированию культурного пространства русской диаспоры на китайской территории.

В последние годы в отечественной и зарубежной науке интерес к истории культуры русского зарубежья продиктован необходимостью возрождения духовных ценностей России. Особая роль в этом принадлежит Харбину как одному из главных центров русской эмиграции на Дальнем Востоке, где задолго до революции существовала русская диаспора, привлечённая строительством Китайско-Восточной железной дороги (КВЖД). Исторические документы хранят следы духовной жизни людей, сумевших создать уникальный островок русской культуры на китайской территории со своими бытом, традициями, обычаями.

Российские поселенцы смогли не только сохранить на китайской земле свою национальную культуру, духовные ценности, языковую и ментальную среду, но в условиях иной культуры создали значительное культурное наследие, дошедшее до нас в виде печати [2, с. 1]. Одним из таких источников является еженедельный общественно-железнодорожный журнал г. Харбина «Железнодорожная жизнь на Дальнем Востоке» (1908-1917 гг., ред. Н.А. Усов) [12, с. 82]. На страницах периодического издания запечатлены события политической, социально-экономической, общественно-культурной жизни русской диаспоры на территории КВЖД. Среди множества фактов наибольший интерес представляют описания массовых праздников и гуляний, позволяющих современникам обратиться к историческому опыту, переосмыслить потерянные в веках духовные ориентиры, идеалы и ценности.

культура, праздник, духовные иенности, традищuи, oбычаu, культурное пространство

Для иитирования:

Андриец Г. А. Русские праздники Харбина начала XX века в системе духовных ценностей Дальнего Востока (на материале журнала «Железнодорожная жизнь на Дальнем Востоке») // Известия Восточного института. 2021. № 3. C. 27-35. DOI https://doi.org/10.24866/25421611/2021-3/27-35 
Несмотря на значительное число публикаций по истории русской культуры дальневосточного зарубежья $[1 ; 2 ; 8 ; 9 ; 13]$ и по истории праздничной культуры как таковой $[1 ; 3 ; 5 ; 6 ; 7 ; 10 ; 11 ; 14]$ проблеме праздников в освещении периодической печати г. Харбина должного внимания не уделялось. А между тем пресса отражает и одновременно формирует общественное мнение, систему представлений о нормах поведения. При этом отдельные, наиболее значимые трактовки традиций редакторов и обозревателей анализируются не как случайные явления, а как характерные проявления господствующих в рассматриваемый период тенденций общественно-культурной жизни [11, c. 15-16]. Журнал «Железнодорожная жизнь на Дальнем Востоке» содержит богатейший фактический материал о праздничных событиях (информацию о публичных культурных мероприятиях и торжествах, о ходе, месте и времени их проведения, оценки очевидцев и т.д.), что позволяет наиболее достоверно представить содержание и динамику общественно-культурных процессов, реконструировать более общие тенденции в истории праздничной культуры.

Цель статьи - рассмотреть основные русские праздники Харбина начала XX века как духовные ценности дальневосточного региона в освещении журнала «Железнодорожная жизнь на Дальнем Востоке». Основное внимание уделим сохранившимся в печати описаниям новогодних торжеств, общероссийских памятных дат, профессиональных юбилеев, детских праздников, народных гуляний. Остановимся на культурном содержании и качестве проведения массовых мероприятий, определяющих уровень духовной жизни русских поселенцев в Китае.

В работе над статьёй нами использован богатый фактический материал, опубликованный на страницах порядка 50 номеров журнала «Железнодорожная жизнь на Дальнем Востоке», печатные экземпляры которого хранятся в фонде периодических изданий Российской государственной библиотеки (г. Москва).

По мнению прессы, обращение к русским традициям объективно обусловлено тоской по Родине. Деятельность по сохранению национальной культуры, системы определённых культурных ценностей, убеждений, обычаев, выражалась в нормах поведения и деятельности людей, что нашло своё отражение в праздничной культуре Харбина. Для праздника - основной составляющей праздничной культуры - характерны основные элементы (обряд, еда, тосты, праздничные пожелания и т.д.), раскрывающие взаимосвязь традиций и обычаев с праздничной культурой. Выполняя просветительскую, нравственную, эстетическую и др. функции, праздник определял потребности, побуждающие людей устраивать торжества (потребность в отдыхе, в удовольствии, в творческом самовыражении и т.д.) [14, с. 13].

Большое желание развлечься, как сообщает журнал, возникало у жителей накануне Нового года, когда в городе устраивались повсеместные новогодние празднества и увеселения. В культурных учреждениях проводились рождественские ёлки, балы, маскарады, вечера отдыха, все поздравляли друг друга с праздником. Например, в 1914 г. «новогодние поздравления в Железнодорожном и Коммерческом собраниях прошли при очень большом стечении публики. Особенно большой съезд наблюдался, по сравнению с прошлым годом, в Коммерческом собрании... В иллюзионах «Декаданс» Б.М. Тер- 
Аракелова и «Гранд-Иллюзион» Дон-Оттело демонстрировалась грандиозная картина «Покорение Кавказа» [4, 1914, № 1-2, с. 17].

С большим воодушевлением проходили детские новогодние ёлки. Так, 4 января 1917 г. ёлка в «Детском маяке» Е.Н. Соколовой доставила много удовольствия обилием развлечений - сценки, живые картины, хоры, дуэты и соло, «микроскопический» по возрасту исполнителей балет, трогательная сценка "Солдат и старушка», жизнерадостные «Кузнецы» и страшный «Стёпка-растрёпка». На празднике дети в возрасте 4-9 лет настолько сдружились, «отлично спелись и сыгрались», что сами себя развлекали, не доставляя забот взрослым [4, 1917, № 2-3, с. 14].

Деятельность журнала стабилизировала пространство повседневности как культурообразующее, наполненное ценностями, символами, создавая условия для появления новых образов и интерпретации каждодневных практик, что способствовало адаптации русского населения к непривычным условиям. В 1911 г. «Железнодорожная жизнь на Дальнем Востоке», как и вся периодическая печать России, освещала важный государственный праздник - 50-летие освобождения крестьян от крепостной зависимости (19 февраля 1861 г.). На страницах издания сообщалось, что к массовым общероссийским торжествам присоединились Коммерческие училища Харбина. В знаменательный день зал учебного заведения был украшен портретами царя и его окружения, декорирован зеленью из сосновых ветвей, щитами с датами исторических событий, флагами. После народного гимна в исполнении смешанного хора и симфонического оркестра директором училища Н.В. Борзовым был прочитан доклад на тему «Акт 19 февраля и обязанности, налагаемые актом на общество», преподавателем истории М.К. Дунаевским - сообщение «Крестьянский вопрос в первой половине XIX столетия», а также ученические рефераты о 19 февраля. Были исполнены музыкально-вокальные произведения и декламации учеников Аршона (стихотворение собственного сочинения «На 19-е февраля»), Туманова («Кузнец» Некрасова), Батракова («Поля» Майкова) и др. Ученик 6-го класса Столяров представил ряд народных песен на балалайке. Публика отметила хор балалаечников под управлением ученика 7-го класса Гуляева и хор учащихся под управлением П.Н. Машина, в исполнении которых прозвучали «Многие лета», «Сеятель», «Воля», «Славься». Праздник посетили Приамурский генерал-губернатор Н.Л. Гондатти и высшие чины управления КВЖД. В память о событии 19 февраля было решено учредить две стипендии на средства членов педагогического комитета для детей крестьянского происхождения, открыть особое отделение при фундаментальной библиотеке, где были бы собраны произведения научной и художественной литературы по крестьянскому вопросу в России $[4,1911$, № 9, с. 17]. Подобные торжества сглаживали отдалённость территорий и формировали дух единения.

Использование основных форм трансляции русской культуры образования, традиций, творчества русских писателей - позволило харбинскому изданию с достоверностью передать подробности праздничных мероприятий, посвящённых знаменитым российским деятелям культуры. Так, к празднованию 100-летия со дня рождения Н.В. Гоголя были привлечены воспитанники местных учебных заведений Харбина, педагоги и в качестве руководителей - служащие 
городской управы. 20 марта 1909 г. Коммерческое училище чествовало юбилей писателя литературным утром, где преподавателем М.К. Дунаевским была прочитана лекция о значении Н.В. Гоголя в русской литературе и заслушаны рефераты учащихся. В концертной программе выступил соединённый хор мужского и женского училищ под управлением П.Н. Машина, на экране демонстрировались «туманные картины» на темы сочинений о Гоголе, прочитана биография писателя. На украшенной цветами сцене был установлен портрет Гоголя, учениками училища удачно разыгран «Ревизор» и сцены из «Майской ночи». Была отмечена хорошая игра ученика Голяновского (Осип) и учениц Вебер и Витте (Мария Андреевна и Мария Антоновна). Детям были розданы брошюры, мелкие сочинения Н.В. Гоголя и угощения [4, 1909, № 11, с. 496]. А 3 мая в театре Арнольдова состоялось торжественное чествование памяти Н.В. Гоголя, устроенное учебным отделом КВЖД для всех учащихся Харбина. На первое по своим масштабам грандиозное гуляние города были приглашены все ученики городских, железнодорожных школ и коммерческих училищ - более 3000 детей. В исполнении соединённого хора учащихся прозвучал народный гимн, кантата, несколько песен. Были разыграны «мелкие сцены из Гоголя, «Ревизор», ставили живые картины» $[4,1909$, № 14, c. 617]. В саду играли два оркестра, один из которых был оркестр 2-го Заамурского железнодорожного батальона под управлением Г.М. Зунделя. В качестве почётных гостей на празднике присутствовали генералы Д.Л. Хорват и М.Е. Афанасьев, распорядителями были начальник учебного отделения Н.В. Борзов, учителя М.П. Баранов, В.Е. Первов и М.Н. Рубин [4, 1909, № 14, с. 617].

Благодаря деятельности периодической печати, решающей задачи реализации культурно-образовательных потребностей, русскому населению в зоне КВЖД удалось сберечь родной язык, сохранить свою культуру. Так, большое внимание «Железнодорожная жизнь на Дальнем Востоке» уделяла местным профессиональным праздникам и юбилеям. В 1913 г. на страницах периодической печати широко освещалось празднование 5-летия библиотеки-читальни служащих КВЖД, состоявшееся 24 ноября. Журнал опубликовал краткий очерк деятельности культурного учреждения, отметив, что библиотека образовалась в результате объединения Общества библиотеки-читальни с библиотекой служащих депо Харбин под председательством А.И. Сабинина. В 1911 г. Общество открыло начальную школу на 80 человек. В 1912 г. школа была преобразована в прогимназию, а в 1913 г. - в «Прогимназию имени генерал-лейтенанта Д.Л. Хорвата» (заведующий А.М. Дорофеев). Число учащихся выросло до 156 чел. Преподавательский состав в количестве 10 чел. вёл обучение в трёх подготовительных и четырёх основных классах. «В настоящее время библиотека-читальня насчитывает 6000 томов сочинений на русском, польском и малороссийском языках». На празднике присутствовали Управляющий дорогой генерал-лейтенант Д.Л. Хорват, его помощник по гражданской части М.Е. Афанасьев, председатель Городского Совета М.С. Уманский и др. [4, 1913, № 45, с. 13].

Обозреватели журнала своим трудом создавали благоприятные условия культурной жизни на далёкой маньчжурской земле, вместе со всеми праздновали успехи других изданий Харбина. Например, 10 июня 1913 г. общественность города отмечала 10-летний юбилей 
газеты «Харбинский Вестник». В честь знаменательного события издание получило поздравительные телеграммы от редактора газеты «Новая Жизнь» С.Р. Чернявского, от редактора газеты «Приамурье» Н.В. Слюнина, приветствия от редактора «Востока» С.В. Полетика, от председателя педагогического общества Н.В. Борзова и др. В ознаменовании торжественного события был сделан сбор «с целью произвести уплату за право учения малоимущих учащихся» (собрано 128 руб.) $[4,1913$, № 23 , с. 11-12].

Социально-культурная активность населения во многом зависела от состояния системы культурно-просветительных учреждений и информационных средств. Являясь одной из традиционных форм массовой коммуникации, пресса выполняла досуговую и просветительскую функцию. Читателям журнала «Железнодорожная жизнь на Дальнем Востоке» запомнилось описание торжественного обеда 26 декабря 1913 г. в честь 10-летия со дня основания одного из первых культурных учреждений города - Харбинского Коммерческого собрания. На празднике присутствовало около 150 человек. Зал был «декорирован и украшен живыми цветами, национальными флагами, гирляндами зелени, между которыми светились разноцветные электрические лампочки. Сцена утопала в экзотических растениях и уютно была убрана коврами и мебелью» $[4,1913$, № 3, с. 1]. Тосты и поздравительные речи произносили управляющий КВЖД генераллейтенант Д.Л. Хорват, председатель комитета старшин М.Э. Гильчер, председатель Городского совета М.С. Уманский и другие. В честь юбилея собрание ассигновало 1000 руб. на общественную гимназию и 1500 руб. на просветительные и благотворительные учреждения Харбина. Отмечено, что традиционно на Новый год и в день Святой Пасхи в Коммерческом собрании собирается всё местное общество, включая представителей администрации Харбина, «для взаимных поздравлений» $[4,1913$, № 3, с. 1-3].

Праздничная культура опиралась на богатейшие культурно-просветительские традиции и была призвана обеспечить превращение культурных достижений, норм, ценностей в воздействующее на каждого человека культурное пространство, которое обеспечивало бы ему наиболее полную адаптацию в современных условиях. Издатели журнала охотно публиковали статьи о праздновании юбилеев отдельных людей, чья деятельность внесла существенный вклад в развитие региона. Например, 20 сентября 1915 г. в Железнодорожном собрании Харбина состоялось торжественное заседание обществ русских ориенталистов, педагогического, сельскохозяйственного и общества народных университетов, посвящённое 80-летнему юбилею известного путешественника и исследователя Г.Н. Потанина по следующей программе: 1) «Г.Н. Потанин, как путешественник и исследователь» - член Общества русских ориенталистов И.И. Петелин; 2) «Г.Н. Потанин в истории просвещения Сибири»- член педагогического общества Н.П. Автономов; 3) «Г.Н. Потанин, как общественный деятель» - член Общества народных университетов М.А. Шейнкман; 4) «Из личных встреч с Г.Н. Потаниным»- член сельскохозяйственного общества В.В. Солдатов [4, 1915, № 35-36, с. 14]. А 19 февраля 1917 г. в Харбине состоялось большое представление по случаю 30-летнего юбилея директора цирка Ф.Я. Изако, который, как отмечалось, вырос в цирковой семье и унаследовал семейные традиции на арене цирка [4, 
1917, № 8, с. 15]. Опубликованные материалы празднований круглых дат и юбилеев отдельных лиц и общественно-культурных учреждений вносили оживление в однообразную жизнь горожан, наполняли духовным содержанием благодарных читателей журнала.

Массовый интерес к праздничной культуре распространялся на детское творчество. Часто торжества с участием детей становились главным культурным событием города. Немаловажно, что пресса не только отражала качественный рост праздника (иногда преувеличенный или надуманный), но и сама его стимулировала публикациями, оценивая значение духовного опыта того времени. Так, с 1909 г. журнал публиковал материал о проведении 9 мая ежегодного гимнастического «Сокольского праздника» в Харбинских коммерческих училищах. Обычно около 300 воспитанников собиралось на ипподроме; под музыку спортсмены показывали гимнастические упражнения на кольцах, брёвнах, параллельных брусьях и турнике. Из лёгкой атлетики вызывали интерес бег на 80 ярдов с 6 препятствиями, бросание диска и прыжки с шестом. Как отмечал наблюдатель, дело физического воспитания детей с каждым годом совершенствуется. Особая заслуга в этом принадлежала директору училища Н.В. Борзову и преподавателю гимнастики Ф.Ф. Брабец $[4,1912$, № 19, с. 20; 1913, № 19, c. 13]. По мнению обозревателя, активное вовлечение детей и подростков в общественную жизнь вызвано стремлением оказать на молодёжь воспитательное воздействие, объединить духовные интересы разных поколений.

Излюбленным сюжетом праздничных публикаций становились различные статьи, рассказы, заметки о культурных событиях за рубежом. Многие из них не относились к праздникам, но имели большой резонанс в обществе. Например, в 1914 г. широко обсуждался случай, произошедший с американским учителем танцев. Некий г-н Андерсон (Кливеленд) был привлечен «К суду за совращение малолетних, выразившееся в обучении их модному танцу “танго”». В свою защиту обвиняемый продемонстрировал элементы танцевального искусства, сплясав прямо на суде. Выступление очень понравилось присутствующим, танец был признан вполне нравственным, а представителя обвинения привлекли к ответственности за недобросовестное обвинение $[4,1914$, № 1-2, с. 20$]$.

Среди многообразия общественных развлечений первое место занимали народные гуляния в скверах, на центральных улицах или в городском саду. Пресса охотно освещала уличные выступления военных оркестров, хоров, фокусников, акробатов, организованных для народа. Так, 19 мая 1912 г. состоялось торжественное открытие сада при Железнодорожном собрании г. Харбина, не оставшееся без внимания. «Пустопорожняя площадь, прилегающая к стенам собрания, превратилась в роскошный сад - клумбы, цветники, деревья, постройки, всё лёгкое, изящное, милое, выросло из под земли. Сад обильно освещён электричеством. Имеется павильон с прохладительными напитками, фруктами и чаем» $[4,1912$, № 21, с. 19-20]. По мнению обозревателя, вечер удался на славу. Публики было свыше 1000 чел., играл симфонический оркестр 2-го Заамурского железнодорожного батальона под управлением Г.М. Зунделя. Также 9 июня 1912 г. при большом стечении публики состоялось торжественное открытие сада и новой веранды для скетинг-ринга при Коммерческом собрании 
[4, 1912, № 23, с. 21]. А 10 мая 1915 г. в городском саду на Пристани местный комитет Союза городов устроил грандиозное народное гуляние с благотворительной целью. Были установлены призовые столбы для лазания, качели и пр. развлечения, прошла лотерея-аллегри, играли два оркестра. Вечером сад был иллюминирован, устроен фейерверк $[4,1915$, № 17, с. 17]. Подобные примеры свидетельствуют о том, что при всём многообразии и пестроте народные праздники Харбина воспринимались как нечто цельное.

Революционные события начала ХХ в., всколыхнувшие всю Россию, затронули русское общество Харбина. Отодвинув все праздники на второй план, устраиваемые демонстрации стали носить идеологический характер. В прессе звучали оптимистические настроения счастья и возрождения к новой жизни. Вот как «Железнодорожная жизнь на Дальнем Востоке» описывает праздник свободы. 15 марта 1917 г. на городской площади Харбина собрались 65 организаций. «Тысячи знамён и флагов, переливаясь цветами радуги, развевались над толпой. Блестели штыки народной армии, украшенные цветами и флажками ряды учащихся. Красивый выезд пожарных дружин убран красными флагами». В полдень в соборе прошла заупокойная литургия, прозвучал похоронный марш «Вы жертвою пали в борьбе роковой». «Над толпой развёртывается красное знамя с горевшими на солнце золотыми словами «Свобода, равенство и братство». Оркестры грянули марсельезу... по площади пронеслось восторженное «ура». Процессия торжественно прошла по городу, знамёна были внесены в здание читальни... Вечером город был иллюминирован» [4, 1917, № 12, с. 11-12].

Таким образом, многочисленные русские праздники дореволюционного Харбина, описанные в журнале «Железнодорожная жизнь на Дальнем Востоке», составляют основное содержание духовной жизни русских людей на китайской территории. Посредством праздничной культуры как таковой и её основного элемента - праздника - периодическое издание выполняло досуговую и просветительскую функции, обеспечивало сохранение культурных традиций, норм, ценностей. Реализуя культурно-образовательные потребности русского населения Харбина, журнал способствовал сохранению национальной культуры и родного языка.

\section{Литература}

1. Аблова Н.Е. КВЖД и российская эмиграция в Китае: международные и политические аспекты истории (первая половина ХХ в.). М.: НП ИД «Русская панорама», 2004. 432 с.

2. Ван Кэвэнь. Русская культура Харбина: историко-культурологический анализ: автореф. дис. ... канд. культурологии. Чита, 2013. 24 с.

3. Дацышен В.Г. Порт-Артур. История одного русского города // Архитектура Восточной Сибири и Дальнего Востока. Вып. 1. Русские города на Дальнем Восто- ке. Хабаровск: Хаб. гос. техн. ун-т, 2002. С. 143-166.

4. Железнодорожная жизнь на Дальнем Востоке. Харбин. 1909, 1911-1915, 1917.

5. Капран И.К. Повседневная жизнь русского населения Харбина (конец XIX 50-е гг. XX в.). Владивосток: Изд-во Дальневост. федерального ун-та, 2011. 204 с.: ил.

6. Капран И.К. Православная музыкальная культура русского Харбина. Владивосток. URL: https://pandia.ru/ text/77/272/58057.php (дата обращения: 
16.10.2021).

7. Мазаев А.И. Праздник как социально-художественное явление. М.: Наука, 1978. $391 \mathrm{c}$.

8. Мелихов Г.В. Белый Харбин: Середина 20-х. М.: Русский путь, 2003. 440 с., ил.

9. Мелихов Г.В. Маньчжурия далёкая и близкая. М.: Наука, 1991. 319 с.

10. Некрылова А.Ф. Русские народные городские праздники, увеселения и зрелища. Конец XVIII - начало XX века. СПб.: Азбука-классика, 2004. 256 с.: ил. + вклейки 16 с.

11. Рогожина Н.Д. Пасхальный праздник в повседневной жизни Петербурга и Москвы в конце XIX - начале XX века: автореф. дис. ... канд. ист. наук. М., 2009. $26 \mathrm{c}$.

12. Стрюченко И.Г. Периодическая печать Дальнего Востока и Забайкалья эпохи капитализма (1861-1917 гг.). Аннотированный библиографический указатель. Владивосток: ДВНЦ АН СССР, 1983. 121 с.

13. Таскина Е.П. Неизвестный Харбин. М.: Прометей, 1994. 192 с.

14. Шматова Н.И. Праздничная культура московского дворянства в последней трети XVIII века: автореф. дис. ... канд. ист. наук. М, 1999. 19 с.

\section{Galina A. ANDRIETS,}

$\mathrm{Ph}$. D. (in History), Research Fellow, Institute of History, Archeology and Ethnography of the Peoples of the Far East (Vladivostok, Russia).

E-mail: andriets2005@list.ru

\section{Russian Holidays in Harbin at the Beginning of the Twentieth Century as Spiritual Values of the Far East (Based on the Material of the Journal "Railway Life in the Far East")}

UDC 947.05(571.6)

Harbin,

culture,

holiday,

spiritual values,

traditions,

customs,

cultural space
DOI https://doi.org/10.24866/2542-1611/2021-3/27-35

The article, based on the material of the journal "Railway Life in the Far East", examines the main Russian holidays in Harbin of the pre-revolutionary period as spiritual values of the Far Eastern region. It is noted that settlers from Russia in a different culture had created a significant cultural heritage that has come down to us in the form of print. It was determined that the publication paid much attention to the coverage of mass holidays and festivities. The article revealed descriptions of New Year's celebrations, allRussian memorable dates, professional anniversaries, children's holidays, and folk festivals. The author comes to the conclusion that the magazine's leisure and educational activities ensured the preservation of cultural traditions, norms, and values, which contributed to the formation of the cultural space of the Russian diaspora on the Chinese territory.

For citation: Andriets G. A. Russian holidays in Harbin at the beginning of the twentieth century as spiritual values of the Far East (based on the material of the journal "Railway life in the Far East") // Oriental Institute Journal. 2021. № 3. P. 27-35. DOI https://doi.org/10.24866/2542-1611/2021-3/27-35 


\section{References}

1. Ablova N.E. KVZHD i rossijskaya ehmigratsiya $\mathrm{v}$ Kitae: mezhdunarodnye i politicheskie aspekty istorii (pervaya polovina XX v.). M.: NP ID «Russkaya panorama», 2004. 432 s.

2. Van Kehvehn'. Russkaya kul'tura KHarbina: istoriko-kul'turologicheskij analiz: avtoref. dis. ... kand. kul'turologii. CHita, 2013. $24 \mathrm{~s}$.

3. Datsyshen V.G. Port-Artur. Istoriya odnogo russkogo goroda // Arkhitektura Vostochnoj Sibiri i Dal'nego Vostoka. Vyp. 1. Russkie goroda na Dal'nem Vostoke. KHabarovsk: KHab. gos. tekhn. un-t, 2002. S. 143-166.

4. ZHeleznodorozhnaya zhizn' na Dal'nem Vostoke. KHarbin. 1909, 1911-1915, 1917.

5. Kapran I.K. Povsednevnaya zhizn' russkogo naseleniya KHarbina (konets XIX - 50-e gg. XX v.). Vladivostok: Izd-vo Dal'nevost. federal'nogo un-ta, 2011. 204 s.: il.

6. Kapran I.K. Pravoslavnaya muzykal'naya kul'tura russkogo KHarbina. Vladivostok. URL: https://pandia.ru/ text/77/272/58057.php (data obrashheniya: 16.10.2021).
7. Mazaev A.I. Prazdnik kak sotsial'nokhudozhestvennoe yavlenie. M.: Nauka, 1978. 391 s.

8. Melikhov G.V. Belyj KHarbin: Seredina 20-kh. M.: Russkij put', 2003. 440 s., il.

9. Melikhov G.V. Man'chzhuriya dalyokaya i blizkaya. M.: Nauka, 1991. 319 s.

10. Nekrylova A.F. Russkie narodnye gorodskie prazdniki, uveseleniya i zrelishha. Konets XVIII - nachalo XX veka. SPb.: Azbuka-klassika, 2004. 256 s.: il. + vklejki $16 \mathrm{~s}$.

11. Rogozhina N.D. Paskhal'nyj prazdnik v povsednevnoj zhizni Peterburga i Moskvy v kontse XIX - nachale XX veka: avtoref. dis. ... kand. ist. nauk. M., 2009. 26 s.

12. Stryuchenko I.G. Periodicheskaya pechat' Dal'nego Vostoka i Zabajkal'ya ehpokhi kapitalizma (1861-1917 gg.). Annotirovannyj bibliograficheskij ukazatel'. Vladivostok: DVNTS AN SSSR, 1983. $121 \mathrm{~s}$.

13. Taskina E.P. Neizvestnyj KHarbin. M.: Prometej, 1994. 192 s.

14. SHmatova N.I. Prazdnichnaya kul'tura moskovskogo dvoryanstva $\mathrm{v}$ poslednej treti XVIII veka: avtoref. dis. ... kand. ist. nauk. M, 1999. $19 \mathrm{~s}$. 